\title{
Effects of Tri-, Di- and Monobutyltin on Synaptic Parameters of the Cholinergic System in the Cerebral Cortex of Mice
}

\author{
Haruo Kobayashi ${ }^{1}$, Tadahiko Suzuki ${ }^{1}$, Yoshinori Kasashima ${ }^{1}$, Akira Motegi ${ }^{1}$, Itaru Sato ${ }^{2}$, Naonori Matsusaka ${ }^{2}$, \\ Naoko Ono ${ }^{1}$, Akemi Miura ${ }^{1}$, Fumiya Saito ${ }^{3}$ and Shin-ya Saito ${ }^{1}$ \\ Departments of 'Veterinary Pharmacology and ${ }^{2}$ Veterinary Public Health, Faculty of Agriculture, Iwate University, Ueda, Morioka 020, Japan \\ ${ }^{3}$ Koiwai Farm Co., Shizukuishi, Iwate 020-05, Japan
}

Received May 10,1996 Accepted September 11, 1996

\begin{abstract}
Triorganotin compounds like tributyltin have been reported to be biodegraded to diorganotin, monoorganotin and then inorganic tin in animals after they have been ingested. Effects of tributyltin, dibutyltin and monobutyltin on various cholinergic parameters that are involved in synaptic transmission in the mouse cerebral cortex were investigated in vitro. Tributyltin and dibutyltin, but not monobutyltin, inhibited the activity of choline acetyltransferase, both the high-affinity and low-affinity uptakes of choline into synaptosomes, and the binding of $\left[{ }^{3} \mathrm{H}\right]$ quinuclidinyl benzilate to muscarinic acetylcholine receptors. Tributyltin and dibutyltin, but not monobutyltin, had a slightly suppressive effect on the $\mathrm{K}^{+}$-induced release and synthesis of acetylcholine in slices of the cortex. All three butyltins at concentrations from $10^{-6}$ to $10^{-4} \mathrm{M}$ had no effect on the activity of acetylcholinesterase. The extent of the inhibitory effects on the cholinergic parameters, apart from the activity of acetylcholinesterase, was slightly greater in the case of tributyltin than dibutyltin, in particularly at the highest concentration $\left(10^{-4} \mathrm{M}\right)$ tested. Therefore, it is concluded that tributyltin metabolites inhibit various parameters of cholinergic activity with a potency ranking of tributyltin $>$ dibutyltin $>$ monobutyltin.
\end{abstract}

Keywords: Cholinergic parameter, Dibutyltin, Monobutyltin, Organotin, Tributyltin

Triorganotin compounds have widespread applications: for example, trimethyltin, tributyltin and triphenyltin are used as agricultural fungicides, molluscicides and as a stabilizer for polyvinyl chloride, and recently the latter two organotins have been used as antifoulants in ship paints and fish-farming nets $(1-3)$. The eventual release and degradation of these materials in the environment have prompted concern about their possible direct or indirect harmful effects on humans and other species.

The involvement of various neurotransmitter systems, such as cholinergic, dopaminergic, gamma-aminobutylic acid (GABA)ergic and excitatory amino acid systems, has been reported in the neurotoxic effects of triorganotins such as trimethyltin, triethyltin and tributyltin (4-9).

Triorganotin compounds, which are hydrophobic, have been reported to be biodegraded to more hydrophilic tin compounds, namely, diorganotin, monoorganotin and subsequently inorganic tin in animals after they have been ingested $(2,10)$. It is known that triorganotin compounds, such as tributyltin, triphenyltin, trimethyltin and triethyltin, have higher toxicity or inhibit the activity of ATPase more effectively than the respective di- and monoorganotin derivatives $(10-12)$.

These reported effects of triorganotins on neurotransmission systems and their biodegrading derivatives including original triorganotins on a biologically basic enzyme, ATPase, and toxicity prompted us to investigate the effects of tributyltin and its derivatives, dibutyltin and monobutyltin, on cholinergic parameters in the cerebral cortex of mice in vitro.

\section{MATERIALS AND METHODS}

\section{Chemicals and animals}

Tri- $n$-butyltin chloride (tributyltin), di- $n$-butyltin dichloride (di-butyltin) and monobutyltin trioxide (monobutyltin) were purchased from Tokyo Chemical Industry (Tokyo). Each tin compound was initially dissolved in Milli-Q water (MQ-water) to $10^{-2} \mathrm{M}$ and then the solutions were diluted further. Fresh solutions were prepared for each experiment. 
Male ICR mice (8- to 12-weeks-old), weighing 35-40 g, were used. After the animals had been decapitated, the cerebral cortex was removed immediately and prepared at $0-4{ }^{\circ} \mathrm{C}$ for the experiments described below.

\section{Assays of enzymatic activity}

The cortex was homogenized in 10 vol. of $0.1 \mathrm{M}$ phosphate buffer $\left(\mathrm{NaH}_{2} \mathrm{PO}_{4}\right.$ plus $\mathrm{K}_{2} \mathrm{HPO}_{4}, \mathrm{pH}$ 8.0) with a Biotron (Biotrona, Kussnacht, Switzerland) at setting 10 for $10 \mathrm{sec}$ at $0^{\circ} \mathrm{C}$. The resultant homogenate was further diluted 20 -fold with the buffer. Then 5 min after the addition of $2.59 \mathrm{ml}$ of phosphate buffer ( $\mathrm{pH} 8.0)$ to $0.4 \mathrm{ml}$ of the diluted homogenate and $0.01 \mathrm{ml}$ of tributyltin, dibutyltin or monobutyltin in a cuvette at $25^{\circ} \mathrm{C}$, the activity of acetylcholinesterase (AChE) was monitored at $25^{\circ} \mathrm{C}$ over the course of $5 \mathrm{~min}$ by the method of Ellman et al. (13) with $0.48 \mathrm{mM}$ acetylthiocholine iodide (AthCh; Nacalai Tesque, Tokyo) as the substrate.

A crude extract containing choline acetyltransferase (ChAT) was prepared by the method of Fonnum (14). The cerebral cortex was homogenized in $0.01 \mathrm{M}$ potassium phosphate buffer $(\mathrm{pH} 6.3)$ that contained $1 \mathrm{mM}$ ethylenediaminetetraacetic acid with a Biotron for $10 \mathrm{sec}$. The homogenate was treated with $0.5 \%$ Triton X-100 at $0^{\circ} \mathrm{C}$ for $30 \mathrm{~min}$ and was then centrifuged at $10^{4} \times g$ for 30 min. The supernatant was used as the preparation of ChAT. The activity of ChAT was determined by the method of Fonnum (14). The reaction mixture contained $0.01 \mathrm{ml}$ buffer substrate (final concentrations of components: $20 \mathrm{mM}$ sodium phosphate buffer, $0.1 \mathrm{mM}$ choline chloride, $0.1 \mathrm{mM}$ neostigmine bromide and $0.1 \mathrm{mM}$ $\left[{ }^{14} \mathrm{C}\right]$ acetyl coenzyme A), $5 \mu 1$ of a solution of tributyltin, dibutyltin or monobutyltin and $5 \mu l$ of the preparation of ChAT. The mixture was preincubated at $0^{\circ} \mathrm{C}$ for $5 \mathrm{~min}$, and then it was supplemented with $0.1 \mathrm{mM}\left[{ }^{14} \mathrm{C}\right]$ acetyl coenzyme A (3.7 MBq/mmol; Radio Chemical Centre, Amersham, Bucks, UK). After incubation at $37^{\circ} \mathrm{C}$ for 30 min, the reaction mixture in the microtube $(1.5 \mathrm{ml})$ was supplemented with $0.1 \mathrm{ml}$ of a $3 \%$ solution of sodium tetraphenyl-boron and centrifuged for $5 \mathrm{~min}$ at $10^{4} \times \mathrm{g}$. A $70-\mu 1$ aliquot of the upper phase was placed in a vial with $6 \mathrm{ml}$ of scintillation fluid (ACS-II, Amersham) in scintillation vials; The radioactivity attributable to tritium was measured in a scintillation counter (LSC-700; Aloka Co., Ltd., Tokyo).

\section{Assay of the uptake of choline}

Cerebral cortex was homogenized in $20 \mathrm{vol}$. of an icecold solution of $0.32 \mathrm{M}$ sucrose in a glass homogenizer with a Teflon pestle, operated at 400-500 rpm with three up-and-down strokes. A crude synaptosomal fraction was prepared by the method of Gray and Whittaker (15). A $0.1-\mathrm{ml}$ aliquot of this crude synaptosomal fraction was added to $0.9 \mathrm{ml}$ of the reaction medium [final concentrations of components: $154 \mathrm{mM} \mathrm{NaCl}, 6.0 \mathrm{mM} \mathrm{KCl}$, $1.6 \mathrm{mM} \mathrm{KH}_{2} \mathrm{PO}_{4}, 1.5 \mathrm{mM} \mathrm{MgSO}, 0.1 \mathrm{mM}$ neostigmine bromide, $1.5 \mathrm{mM} \mathrm{CaCl}, 10 \mathrm{mM}$ glucose, $24 \mathrm{mM}$ $\mathrm{NaHCO}_{3}$ and $\left[{ }^{3} \mathrm{H}\right]$ choline chloride, $0.5 \mu \mathrm{M}$ for highaffinity uptake of choline (HACU) and $50 \mu \mathrm{M}$ for lowaffinity uptake of choline (LACU)] supplemented with tributyltin, dibutyltin or monobutyltin at $10^{-6}$ to $10^{-4} \mathrm{M}$. The radioactive tracer used was $\left[1-\right.$ methyl $\left.{ }^{3} \mathrm{H}\right]$ choline chloride $(2.89 \mathrm{TBq} / \mathrm{mmol}$; New England Nuclear, Boston, MA, USA). After preincubation at $0^{\circ} \mathrm{C}$ for 5 min, the reaction mixtures, except for the null control that was kept at $0^{\circ} \mathrm{C}$, were incubated at $37^{\circ} \mathrm{C}$ for $4 \mathrm{~min}$, and the reaction was terminated by filtration through a GF/B glass-microfiber filter ( $24 \mathrm{~mm} \phi$; Whatman International, Ltd., Maidston, England). The filter was washed with $10 \mathrm{ml}$ and then with $5 \mathrm{ml}$ of ice-cold $0.16 \mathrm{M}$ saline. Each filter was soaked overnight in $6 \mathrm{ml}$ of ACS-II in scintillation vials, and then the radioactivity attributable to tritium was measured in a scintillation counter.

\section{Examination of muscarinic acetylcholine receptors}

The cortex was homogenized in $20 \mathrm{vol}$. of ice-cold 0.32 $M$ sucrose solution in a Teflon-pestle homogenizer, and then the homogenate was centrifuged at $1,000 \times g$ for 10 $\min$ at $0^{\circ} \mathrm{C}$. The supernatant was further homogenized with the Biotron and then used to assay the binding of $\left[{ }^{3} \mathrm{H}\right]$ quinuclidinyl benzilate (QNB) to muscarinic acetylcholine receptors (mAChRs) (16). A 30- $\mu$ laliquot of the preparation, $0.95 \mathrm{ml}$ of Tris- $\mathrm{HCl}$ buffer $(20 \mathrm{mM}$ Tris, 120 $\mathrm{mM} \mathrm{NaCl}, 5 \mathrm{mM} \mathrm{KCl}, \mathrm{pH} 7.4$ ), and $0.01 \mathrm{ml}$ of a $0-$ $10{ }^{4} \mathrm{M}$ solution of tributyltin, dibutyltin or monobutyltin were incubated with $0.01 \mathrm{ml}$ of $10^{-9} \mathrm{M}$ or $5.0 \times 10^{-9}$ $M\left[{ }^{3} \mathrm{H}\right] \mathrm{QNB}$ (1.57 TBq/mmol, New England Nuclear) in the presence or absence of $1 \mu \mathrm{M}$ atropine at $25^{\circ} \mathrm{C}$ for 40 $\mathrm{min}$. The reaction was terminated by filtration through a GF/B glass-fiber filter (17). The filter was washed twice with $5 \mathrm{ml}$ of ice-cold Tris buffer. The radioactivity was measured as described above.

\section{Experiments with tissue slices}

Slices of cortex (0.4-mm-thick) were prepared with a Mcllwain-type automicrochopper in a cold-room $\left(3 \pm 1{ }^{\circ} \mathrm{C}\right)$. A $100-\mathrm{mg}$ sample of the slices were suspended in $1 \mathrm{ml}$ of normal Krebs-Ringer buffer (final concentrations of components: $154 \mathrm{mM} \mathrm{NaCl}, 6.0 \mathrm{mM} \mathrm{KCl}, 1.6 \mathrm{mM}$ $\mathrm{KH}_{2} \mathrm{PO}_{4}, 1.5 \mathrm{mM} \mathrm{MgSO}_{4}, 0.1 \mathrm{mM}$ neostigmine bromide, $1.5 \mathrm{mM} \mathrm{CaCl}_{2}, 10 \mathrm{mM}$ glucose, $24 \mathrm{mM} \mathrm{NaHCO}$ and $0.001 \mathrm{mM}$ physostigmine salicylate) for examination of the normal medium condition (normal control) or high$\mathrm{K}^{+}$medium (the $\mathrm{K}^{+}$concentration was elevated to $30 \mathrm{mM}$ by adding $\mathrm{KCl}$ and removing an equimolar amount of $\mathrm{NaCl}$ ) for examination of the depolarized release condi- 
tion. After addition of tributyltin, dibutyltin or monobutyltin at a given concentration, each suspension of tissue was incubated in an atmosphere of $95 \% \mathrm{O}_{2}$ and $5 \% \mathrm{CO}_{2}$ for $20 \mathrm{~min}$ at $0^{\circ} \mathrm{C}$ and then at $37^{\circ} \mathrm{C}$ or at $0^{\circ} \mathrm{C}$ (to serve as a null control) for $30 \mathrm{~min}$ in the same atmosphere with shaking. Each suspension was centrifuged at $5,000 \times g$ for $20 \mathrm{~min}$ at $0^{\circ} \mathrm{C}$. The supernatant, which contained released acetylcholine (ACh), was supplemented with $0.01 \mathrm{ml}$ of ethylhomocholine as an internal standard and filtrated through a filter (type $\mathrm{HV}$, pore size $0.45 \mu \mathrm{m}$; Millipore Japan Ltd., Tokyo). To extract ACh from the tissue slices, the pellet was resuspended in $1 \mathrm{ml}$ of Krebs Ringer buffer. The suspension was adjusted to $\mathrm{pH} 4$ with $1 \mathrm{M} \mathrm{HCl}$ and immersed in boiling water for $2 \mathrm{~min}$. After adjustment to pH 6.8 with $1 \mathrm{M} \mathrm{NaOH}$, the suspension was centrifuged at $2,000 \times g$ for $10 \mathrm{~min}$ at $0^{\circ} \mathrm{C}$. The supernatant was supplemented with $0.01 \mathrm{ml}$ of ethylhomocholine as an internal standard and filtered. The concentrations of $\mathrm{ACh}$ in the two supernatants were determined by high-pressure liquid chromatography on an enzyme column (Eicom AC-Enzympak, $6.0 \mathrm{~mm}$ diameter $\times 150 \mathrm{~mm}$; Eicom Co., Ltd., Kyoto) equipped with an electrochemical detector (model ECD-100; Eicom Co., Ltd.). The released ACh was the difference in ACh contained in the supernatant before and after incubation. The synthesized ACh was the difference in ACh contained in the sum of the supernatant and slices before and after incubation.

\section{Quantitation of protein}

Protein was quantitated by the method of Lowry et al. (18) with bovine serum albumin as the standard.

\section{Statistics}

Data are expressed as means \pm S.E.M. from at least four experiments done in triplicate. Single comparisons between two groups for determinations of statistical significance of differences were performed by independent Student's $t$-tests. Comparisons between more than two groups were made by analysis of variance with Duncan post hoc analysis.

\section{RESULTS}

\section{Effects on the activity of acetylcholinesterase}

The effects of tributyltin, dibutyltin and monobutyltin on the activity of $\mathrm{AChE}$ in a homogenate of the mouse cortex were examined. The control activity was $16.10 \pm$ $0.33 \mu \mathrm{mol}$ AthCh hydrolyzed $/ \mathrm{min} / \mathrm{g}(\mathrm{n}=12)$ at $25^{\circ} \mathrm{C}$. Tributyltin, dibutyltin and monobutyltin over the concentration range of $10^{-6}$ to $10^{-4} \mathrm{M}$ did not have any effect on the activity of AChE (Fig. 1A).

\section{Effects on the activity of choline acetyltransferase}

The effects of tributyltin, dibutyltin and monobutyltin on the activity of ChAT in the preparation were examined. The control activity was $0.291 \pm 0.014 \times 10^{9} \mathrm{~mol}$ ACh synthesized/mg protein/min $(n=12)$. As shown in Fig. 1B, tributyltin and dibutyltin, but not monobutyltin, inhibited the activity by about $75 \%$ and $72 \%$, respective$\mathrm{y}$, at a concentration of $10^{-4} \mathrm{M}$. There was no significant difference between the inhibitory effect of tributyltin and that of dibutyltin.

\section{Effects on the high-affinity uptake of choline}

The HACU by synaptosomes was measured in the presence of tributyltin, dibutyltin and monobutyltin. The control value was $10.67 \pm 1.00 \times 10^{-12} \mathrm{~mol}$ choline $/ \mathrm{mg}$
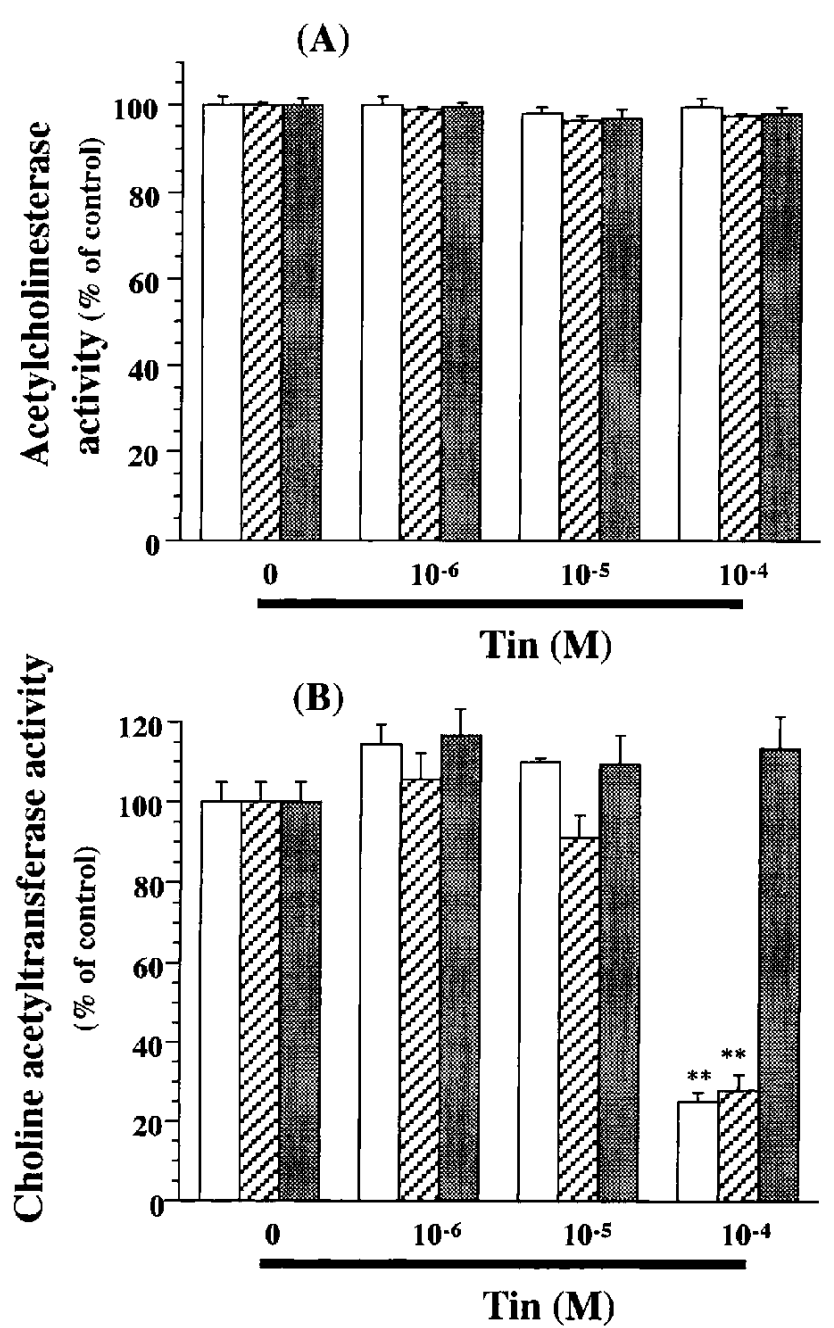

Fig. 1. Effects of tributyltin, dibutyltin and monobutyltin on the activities of acetylcholinesterase (A) and choline acetyltransferase (B). Data are expressed as mean percentages of the control \pm S.E.M. for 4-12 experiments. Tributyltin ( $\square$ ), dibutyltin ( tin (霘). Asterisks indicate experimental values that are significantly different from the respective control $(0 \mathrm{M})$ values $\left({ }^{* *} \mathrm{P}<0.01\right)$. 
protein/min $(n=12)$. As shown in Fig. $2 A$, tributyltin and dibutyltin, but not monobutyltin, inhibited HACU in a dose-dependent manner over the concentration range of $10^{-6}$ to $10^{-4} \mathrm{M}$. At $10^{-4} \mathrm{M}$, the inhibitory effect of tributyltin was significantly greater than that of dibutyltin.

\section{Effects on the low-affinity uptake of choline}

The effects of tributyltin, dibutyltin and monobutyltin on LACU by the crude preparation of synaptosomes were examined. The control activity was $132.2 \pm 11.0 \times 10^{-12}$ $\mathrm{mol}$ choline/mg protein/min $(n=12)$. As shown in Fig. 2B, tributyltin and dibutyltin, but not monobutyltin, inhibited LACU in a dose-dependent manner at concentra-

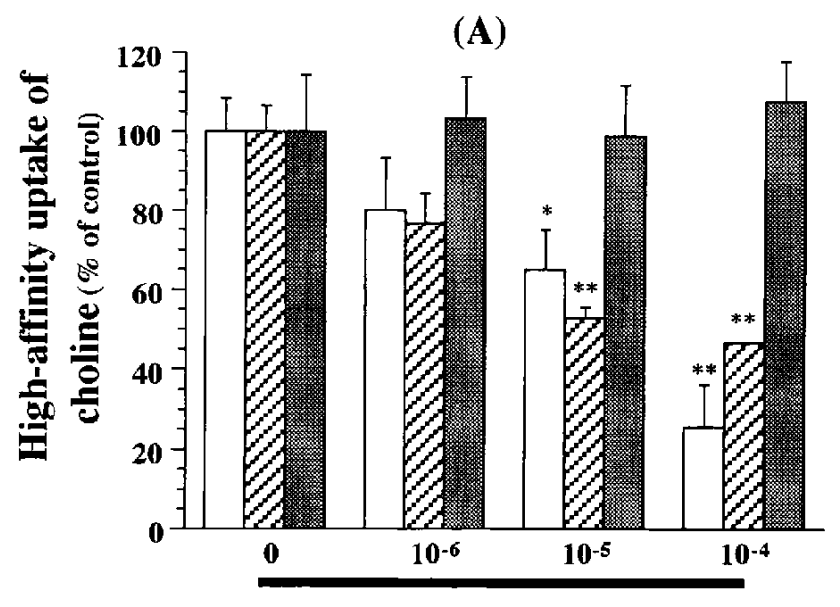

$\operatorname{Tin}(\mathbf{M})$

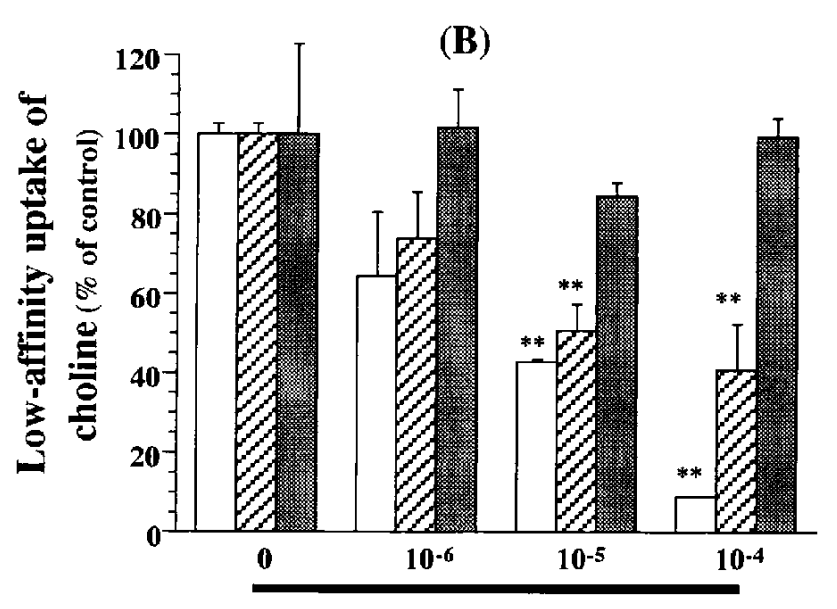

$\operatorname{Tin}(\mathbf{M})$

Fig. 2. Effects of tributyltin, dibutyltin and monobutyltin on the high-affinity uptake (A) and the low-affinity uptake (B) of choline into a crude preparation of synaptosomes. Data are expressed as mean percentages of the control \pm S.E.M. for 4-12 experiments. Tributyltin ( $\square$ ), dibutyltin ( cate experimental values that are significantly different from the respective control $(0 \mathrm{M})\left({ }^{*} \mathrm{P}<0.05,{ }^{* *} \mathrm{P}<0.01\right)$. tions from $10^{-6}$ to $10^{4} \mathrm{M}$. The effect of tributyltin was greater than that of dibutyltin, in particular at $10^{-4} \mathrm{M}$.

\section{Effects on the binding of $\left[{ }^{3} \mathrm{H}\right] q$ uinuclidinyl benzilate}

To clarify the effects of tributyltin, dibutyltin and monobutyltin on muscarinic receptors, the binding of $\left[{ }^{3} \mathrm{H}\right] \mathrm{QNB}$ was examined in the presence of these organotin compounds. The control binding activity was $0.831 \pm$ 0.016 and $1.650 \pm 0.111 \times 10^{-12} \mathrm{~mol}\left[^{3} \mathrm{H}\right] \mathrm{QNB} / \mathrm{mg}$ protein in the presence of $1 \times 10^{-10}$ and $5 \times 10^{-10} \mathrm{M}\left[{ }^{3} \mathrm{H}\right] \mathrm{QNB}$. As shown in Fig. 3 (A and B), tributyltin and dibutyltin, but not monobutyltin, inhibited the binding of $\left[{ }^{3} \mathrm{H}\right] \mathrm{QNB}$ to the preparation of $\mathrm{mAChRs}$ in a dose-dependent manner

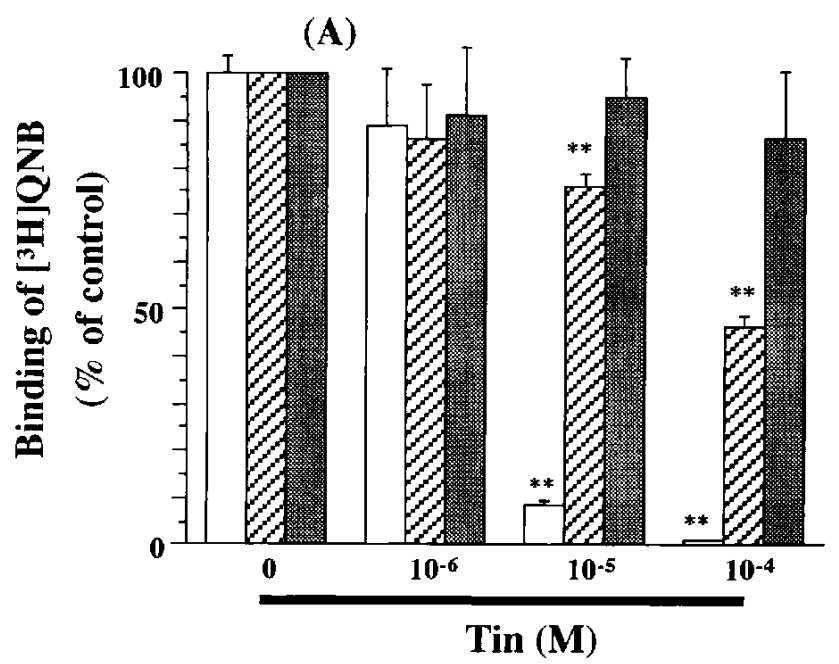

(B)

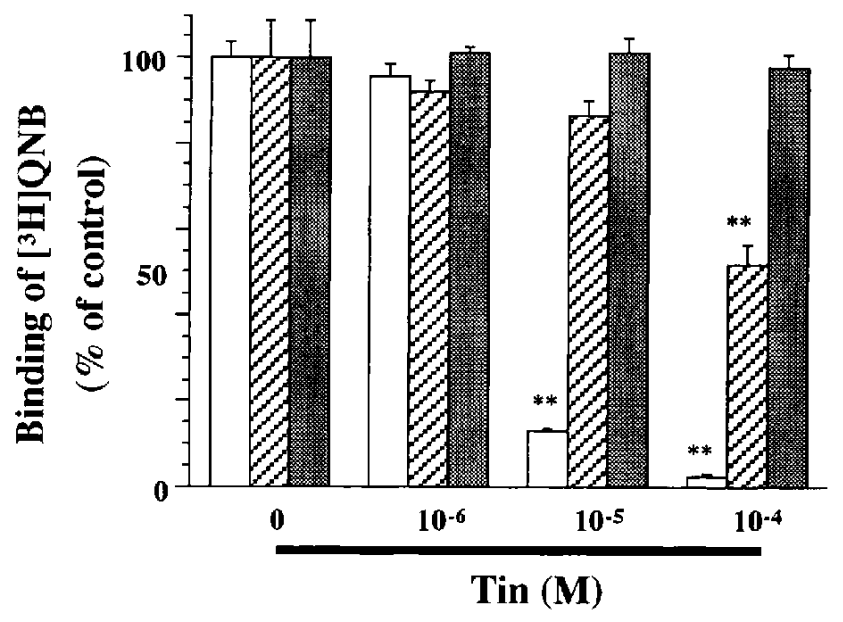

Fig. 3. Effects of tributyltin, dibutyltin and monobutyltin on the binding of $\left[{ }^{3} \mathrm{H}\right]$ quinuclidinyl benzilate $(\mathrm{QNB})$ in the presence of $1 \times 10^{-10}(\mathrm{~A})$ and of $5 \times 10^{-10} \mathrm{M}(\mathrm{B})\left[{ }^{3} \mathrm{H}\right] \mathrm{QNB}$ to the preparation of muscarinic acetylcholine receptor. Data are expressed as mean percentages of the control \pm S.E.M. for $4-12$ experiments. Tributyltin $(\square)$, dibutyltin (®a), monobutyltin (E). Asterisks indicate experimental values that are significantly different from the respective control (0 M) $\left.{ }^{* *} \mathrm{P}<0.01\right)$. 
in the presence of $1 \times 10^{-10}$ or $5 \times 10^{-10} \mathrm{M}\left[{ }^{3} \mathrm{H}\right] \mathrm{QNB}$. The inhibitory effect of tributyltin was significantly greater than that of dibutyltin.

\section{Effects on the release and synthesis of acetylcholine}

The effects of tributyltin, dibutyltin and monobutyltin
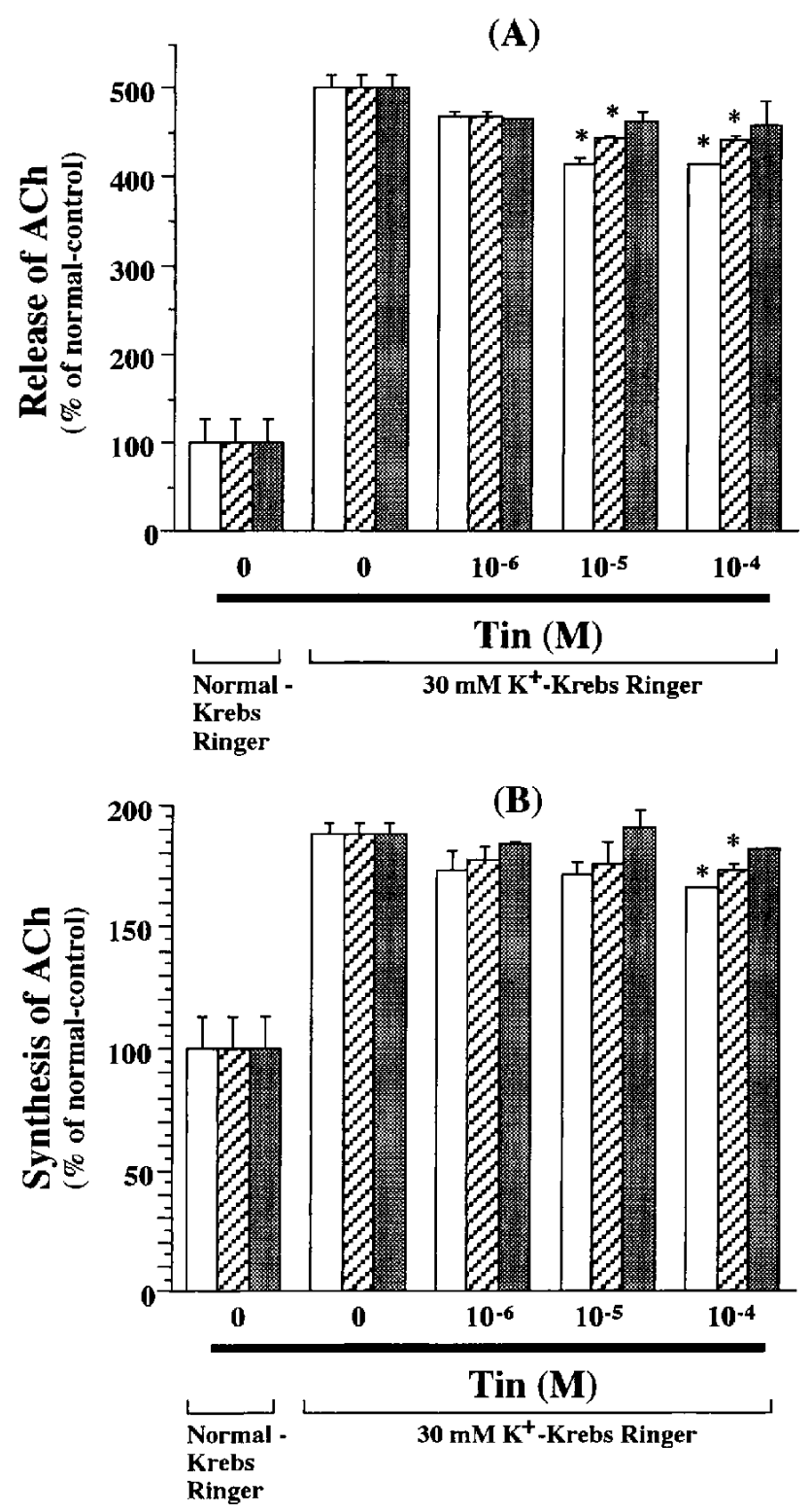

Fig. 4. Effects of tributyltin, dibutyltin and monobutyltin on the release (A) and the synthesis (B) of acetylcholine (ACh) by the cerebral slices. The slices were incubated in the normal Krebs Ringer solution in the absence of tin compounds (normal-control) of and in the $30 \mathrm{mM} \mathrm{K}^{+}$-Krebs Ringer solution in the absence or presence of tin compounds. Data are expressed as mean percentages of normalcontrol \pm S.E.M. for 4-12 experiments. Tributyltin $(\square)$, dibutyltin (『), monobutyltin ( $\square$ ). Asterisks indicate experimental values that are significantly different from the respective control $(0 \mathrm{M})$ $\left({ }^{*} \mathrm{P}<0.05\right)$. on the depolarized release and synthesis of $\mathrm{ACh}$ in slices of cortex were examined over the concentration range of $10^{-6}$ to $10^{-4} \mathrm{M}$. The control values for the release and synthesis of ACh were $2.11 \pm 0.56$ and $5.46 \pm 0.75(n=5)$ in the normal control and $10.56 \pm 0.31$ and $10.26 \pm 0.26 \times$ $10^{-9} \mathrm{~mol} / \mathrm{g}$ slices $/ \mathrm{hr}$ in the depolarized condition $(\mathrm{n}=4)$, respectively. As shown in Fig. $4 \mathrm{~A}$, tributyltin and dibutyltin, but not monobutyltin, slightly inhibited the release of $\mathrm{ACh}$ at concentrations of $10^{-5}$ and $10^{-6} \mathrm{M}$. Tributyltin was a little more effective than dibutyltin. The effects of tributyltin, dibutyltin and monobutyltin on the synthesis of $\mathrm{ACh}$ are shown in Fig. 4B: tributyltin and dibutyltin at $10^{-4} \mathrm{M}$, but not monobutyltin, slightly inhibited the synthesis of $\mathrm{ACh}$.

\section{DISCUSSION}

As expected from a previous study (19), in which it was found that tributyltin and trimethyltin had no effect on the activity of $\mathrm{AChE}$ in a homogenate of chicken cerebrum over the concentration range of $10^{6}$ to $10^{-4} \mathrm{M}$, not only tributyltin but also dibutyltin and monobutyltin had no significant effects on the activity of AChE in the present experiments. Therefore the direct effect of tributyltin and its derivatives on the activity may be negligible, although an indirect effect that was an enhancement of staining for AChE in the dentate gyrus was reported in rats examined 4 months after gavage with trimethyltin (20).

Several reports concluded that a potency ranking with which organic derivatives of tin affect the neural cells, fibroblastic cells and cytoskeletal organization in human neutrophils correlates with the lipophilicity of tin derivatives $(12,21)$. Monobutyltin, which is more hydrophilic than tributyltin and dibutyltin (1), failed to inhibit the activity of ChAT in the present experiments. We reported previously that tributyltin inhibited the activity of ChAT more effectively than trimethyltin (19), which is more hydrophilic than tributyltin (1). ChAT contains the sulfhydryl group of a cysteine residue and the imidazole group of a histidine residue, both of which are at or near the active site and are surrounded by a hydrophobic region within the ChAT molecule (22). Because of its lower solubility in lipids, monobutyltin may not be able to gain access to the active site within the ChAT molecule. The inhibitory effects of tributyltin and dibutyltin on the activity of ChAT were almost the same. It has been reported that the inhibitory effect of tributyltin on the activity of ChAT is attributable to an interaction with imidazole groups but not with sulfhydryl groups in the enzyme (19). Moreover, the effects of dialkyltins, such as diethyltin and dibutyltin, on the activity of ATPase have been reported to be due to an interaction with sulfhydryl 
groups in the ATPase $(2,11)$. Dibutyltin is less lipophilic than tributyltin (1). Although it is unclear why the inhibitory effects of tributyltin and dibutyltin on the activity of ChAT were almost equivalent, it is possible that dibutyltin can interact with the imidazole groups and sulfhydryl groups inspite of the fact that it is less lipophilic than tributyltin or that the lipophilicity is adequate to gain access to the active site within the enzyme molecule. In contrast to the dirrect inhibitory effects of tributyltin and dibutyltin in vitro in the present experiment, an increase in the activity of ChAT in the dentate gyrus was reported in rats 3 to 21 days after gavage with trimethyltin $(6 \mathrm{mg} / \mathrm{kg})(5)$.

It has been reported that tributyltin, trimethyltin and methylmercury inhibit the HACU noncompetitively (19, 23), while hemicholinium-3 inhibits HACU competitively (24) by interacting with the choline transporter that is surrounded by a hydrophobic region (25). It has been suggested that tributyltin and trimethyltin affect the HACU via some component(s) other than sulfhydryl groups, but methylmercury acts via sulfhydryl groups in or around the transporter $(19,23,26)$. Tributyltin was, however, found previously to be about 14-fold more potent than trimethyltin, which has a lower solubility in lipids than tributyltin, in inhibiting the HACU (19). Tributyltin and dibutyltin, but not monobutyltin, were found to inhibit the HACU in the present experiments. It seems, therefore, that monobutyltin was unable to affect the HACU because of its low solubility in lipids, while tributyltin and dibutyltin inhibited HACU via some component(s) other than sulfhydryl groups and with sulfhydryl groups, respectively. The HACU is an active process that is mediated by $\mathrm{Na}^{+}, \mathrm{K}^{+}$-ATPase in the terminal membranes of cholinergic nerve (27). It has been reported that triorganotin and diorganotin compounds can inhibit the activity of $\mathrm{Na}^{+}, \mathrm{K}^{+}$-ATPase $(2,11,12)$. Since tributyltin is more lipophilic than dibutyltin (1), it seems plausible that the former could inhibit the HACU more effectively than the latter at a concentration of $10^{-4} \mathrm{M}$.

Unlike the HACU, which is accepted to occur specifically in the presynaptic membranes of cholinergic nerve terminals (28), the LACU is generally believed to be localized nonspecifically in the presynaptic membranes of various nerve terminals and to be involved in supplying the substrate, choline, for certain phospholipids, although there are some opposing views $(29,30)$. The lipids are the major constituents of all biological membranes, including the presynaptic membranes of various nerve terminals (31). Similar to our previous report (19) in which synaptosomes were prepared from chicken cerebrum, tributyltin inhibited the LACU. The order of potency in the inhibition of the LACU was tributyltin, dibutyltin, and monobutyltin, and monobutyltin had no effect on the LACU within the concentration range of $10^{-6}$ to $10^{-4} \mathrm{M}$ in the present experiments. This rank order is similar to the rank order of solubility in lipids (1). The previous report indicated that tributyltin was more effective than trimethyltin, a less lipophilic triorganotin, in inhibiting the LACU (19). It seems, therefore, that the efficiency of butyltin in inhibiting the LACU is related more or less to its lipophilicity.

Tributyltin is known to inhibit the binding ability of $\left[{ }^{3} \mathrm{H}\right] \mathrm{QNB}(19)$. To examine if the effects of butyltin compounds on the $\mathrm{mAChR}$ depend on the concentration of ligand, two concentrations of $\left[{ }^{3} \mathrm{H}\right] \mathrm{QNB}$ was used in the present study. Although both tributyltin and dibutyltin inhibited the binding of $\left[{ }^{3} \mathrm{H}\right] \mathrm{QNB}$ in a dose-dependent manner, their effects were apparently independent of the concentration of $\left[{ }^{3} \mathrm{H}\right] \mathrm{QNB}$. The inhibitory effect was greater with the more lipophilic tributyltin than with the less lipophilic dibutyltin. Similar to a previous study in which hydrophilic trimethyltin did not affect the binding of $\left[{ }^{3} \mathrm{H}\right] \mathrm{QNB}$ (19), hydrophilic monobutyltin had no effect on the binding of $\left[{ }^{3} \mathrm{H}\right] \mathrm{QNB}$ within the concentration range of $10^{-6}$ to $10^{-4} \mathrm{M}$ during incubations for $40 \mathrm{~min}$ at $25^{\circ} \mathrm{C}$ in the present experiments. Loullis et al. (32) detected a histochemically apparent decrease in hippocampal mAChRs by monitoring the binding of $\left[{ }^{3} \mathrm{H}\right] \mathrm{QNB}$ in rats 2 weeks after the administration of trimethyltin (3.5 $\mathrm{mg} / \mathrm{kg}$ ). The difference in potency for inhibition of such binding between the three butyltins seems due to their differences in lipophilicity, although differences in the direct effects of the organotins on mAChRs cannot yet be ruled out.

Tributyltin and dibutyltin at concentrations of $10^{-5}$ and $10^{-4} \mathrm{M}$ were found to inhibit the evoked release of $\mathrm{ACh}$ from slices of cerebral cortex in the present experiments, while monobutyltin was ineffective. Decreased release of ACh might occur when mechanisms responsible for the release of $\mathrm{ACh}$ are inhibited and/or the synthesis of ACh is suppressed (28). Because tributyltin and dibutyltin inhibited the synthesis of $\mathrm{ACh}$ in the slices only at a concentration of $10^{4} \mathrm{M}$, their effects on the release of ACh from the slices might reflect both possible mechanisms, inhibition of the synthesis and release of ACh. Previously we reported that tributyltin inhibited the release of $\mathrm{ACh}$ from cerebral slices of chicken a little more effectively than trimethyltin, which is more hydrophilic than tributyltin (19). Tributyltin was slightly more effective in inhibiting the release of $\mathrm{ACh}$ than dibutyltin, which is thought to be more hydrophilic than tributyltin, in the present experiments. Therefore, it seems likely that unlike tributyltin and dibutyltin, monobutyltin is unable to dissolve in or diffuse through lipid-rich membranes, which may be involved in mecha- 
nisms of $\mathrm{ACh}$ release.

Suppression of the synthesis of ACh caused by $10^{-4} \mathrm{M}$ tributyltin and dibutyltin in the slices of cortex may have been due to suppression of HACU and ChAT, which are considered to be the main factors that control the synthesis of ACh (28) and/or LACU, which is thought to be involved in supplying the choline for membrane phospholipids and eventually for $\mathrm{ACh}$ (31). It seems reasonable that monobutyltin had no effect on the synthesis of $\mathrm{ACh}$ in the slices because this organotin did not cause any changes in the various parameters involved the synthesis of ACh such as HACU, ChAT and LACU, as described above.

In summary, our data demonstrate that tributyltin and dibutyltin, but not monobutyltin, inhibited various parameters of cholinergic activity that are involved in synaptic transmission, with the exception of the activity of acetylcholinesterase, with a potency ranking of tributyltin $>$ dibutyltin $>$ monobutyltin. This ranking seems to correlate with the rank order of lipophilicity of these organotins. It is known that some triorganotins and certain metabolites inhibit the uptake of GABA into synaptosomes (32). It is interesting to note that the order of inhibitory potency is triphenyltin $>$ tripropyltin $>$ tributyltin $>$ triethyltin $>$ trimethyltin $>$ dimethyltin $>$ monomethyltin $>$ tin chloride (inorganic tin) (32). This rank from trimethyltin to monomethyltin is very similar to the present results. Since the tributyltin compound is destannylated to dibutyltin, monobutyltin and inorganic tin in mammals and birds after ingestion $(2,10,33)$, it is possible that probability of the neurotoxicity that involves cholinergic nervous mechanisms might depend on the duration of retention of the organotins as tributyltin and dibutyltin in this nervous system.

It has been reported that the mean amounts of tributyltin and dibutyltin in the rat brain 24 to $72 \mathrm{hr}$ after a single injection of tributyltin, supplied as about $1 / 3$ $\mathrm{LD}_{50}$, were about 10 to 6 and about 6 to $3 \mu \mathrm{mol} / \mathrm{kg}$ wet tissue (10), mean levels that correspond approximately to 10 to $6 \mu \mathrm{M}$ tributyltin and 6 to $3 \mu \mathrm{M}$ dibutyltin, respectively. Therefore, from the results obtained in the present experiments, at least the concentration of tributyltin or dibutyltin in the brain of animals exposed to tributyltin might be considerable and sufficient to suppress the factors involved in cholinergic mechanisms such as the activity of ChAT, the HACU, LACU and MAChR.

\section{REFERENCES}

1 Magos L: Tin. In Handbook on the Toxicology of Metals, Edited by Friberg L, Nordberg GF and Vouk V, Vol 2, 2nd Edition, pp 298-353, Elsevier, Amsterdam (1986)

2 Snoeij NJ, Penninks AH and Seinen W: Biological activity of organotin compounds. An overview. Environ Res 44, 335-353
(1987)

3 WHO: Tributyltin compounds. In Environmental Health Criteria 116, pp 1-227, World Health Organization, Geneva (1990)

4 Andersson H, Radesater A-C and Luthman J: Trimethyltininduced loss of NMDA and kinate receptors in the rat brain. Amino Acids 8, 23-35 (1995)

5 Cannon RL, Hoover DB, Baisden RH and Woodruff ML: Effects of trimethyltin (TMT) on choline acetyltransferase activity in the rat hippocampus. Influence of dose and time following exposure. Mol Chem Neuropathol 23, 27-45 (1994)

6 Cannon RL, Hoover DB, Baisden RH and Woodruff ML: Effect of time following exposure to trimethyltin (TMT) on cholinergic muscarinic receptor binding in rat hippocampus. Mol Chem Neuropathol 23, 47-62 (1994)

7 Chang LW: The concept of direct and indirect neurotoxicity and the concept of toxic metal/essential element interactions as a common biomechanism underlying metal toxicity. In The Vulnerable Brain and Environmental Risks. Toxin in Food, Edited by Isaacson RL and Jensen KF, Vol 2, pp 61-82, Plenum Press, New York (1992)

8 Kobayashi H, Suzuki T, Sato I and Matsusaka N: Neurotoxicological aspects of heavy metal compounds. Toxicol Ecotoxicol News 1, 23-30 (1994)

9 McMillan DE and Wenger GR: Neurobehavioral toxicology of trialkyltins. Pharmacol Rev 37, 365-379 (1985)

10 Iwai $\mathrm{H}$, Wada $\mathrm{O}$ and Arakawa $\mathrm{Y}$ : Determination of tri-, di-, and mono-butyltin and inorganic tin in biological materials and some aspects of their metabolism in rats. $\mathbf{J}$ Anal Toxicol $\mathbf{5}$, 300-306 (1981)

11 Aldridge WN and Cremer JE: The biochemistry of organotin compounds. Biochem J 61, 406-418 (1955)

12 Borenfreund $\mathrm{E}$ and Babich $\mathrm{H}$ : In vitro cytotoxicity of heavy metals, acrylamide, and organotin salts to neural cells and fibroblasts. Cell Biol Toxicol 3, 63-73 (1987)

13 Ellman GL, Courtney KD, Andres V and Featherstone RM: A new and rapid colorimetric determination of acetylcholinesterase activity. Biochem Pharmacol 7, 88-95 (1961)

14 Fonnum F: Isolation of choline esters from aqueous solution by extraction with sodium tetraphenylboron in organic solvents. Biochem J 113, 291-298 (1969)

15 Gray EG and Whittaker VP: The isolation of nerve ending from brain. An electron microscopic study of cell fragments derived by homogenization and centrifugation. J Anat 96, 78-88 (1962)

16 Kobayashi $H$, Yuyama A, Ishihara $M$ and Matsusaka N: Effects of arsenic on cholinergic parameters in brain in vitro. Neuropharmacology 26, $1707-1713$ (1987)

17 Yamamura HI and Snyder S: Muscarinic cholinergic binding in rat brain. Proc Natl Acad Sci USA 71, 1725-1729 (1974)

18 Lowry OH, Rosebrough NJ, Farr AL and Randall RJ: Protein measurement with the Folin phenol reagent. J Biol Chem 193, $265-275$ (1951)

19 Kobayashi H, Saito F and Yuyama A: Effects of organotins on the cholinergic system in the chicken brain in vitro. Toxicol In Vitro 6, 337-343 (1992)

20 Woodruff ML and Baisden RH: Exposure to trimethyltin significantly enhances acetylcholinesterase staining in the rat dentate gyrus. Neurotoxicol Teratol 12, 33-39 (1990)

21 Marinovich M, Sanghvi A, Colli S, Tremoli E and Galli CL: Cytoskeletal modifications induced by organotin compounds in 
human neutrophils. Toxicol In Vitro 4, $109-113$ (1990)

22 Chao L-P: Choline acetyltransferase: purification and characterization. J Neurosci Res 5, 85-115 (1980)

23 Kobayashi $H$, Yuyama A, Matsusaka N, Takeno $K$ and Yanagiya I: Effects of methylmercury chloride on various cholinergic parameters in vitro. J Toxicol Sci 4, 351-362 (1979)

24 Chatterjee TK, Long JP, Cannon JG and Bhatnagar PK: Methylpiperidine analog of hemicholinium-3: a selective, high affinity non-competitive inhibitor of sodium dependent choline uptake system. Eur J Pharmacol 149, 241-248 (1988)

25 Tamaru $M$ and Roberts EI: Structure-activity studies on inhibition of choline uptake by a mouse brain synaptosomal preparation: basic data. Brain Res 473, 205-226 (1988)

26 Bondy SC, Anderson CL, Harrington ME and Prasad KN: The effects of organic and inorganic lead and mercury on neurotransmitter high-affinity transport and release mechanisms. Environ Res 19, 102-111 (1979)

27 Simon JR, Atweh S and Kuhar MJ: Sodium dependent high affinity choline uptake: a regulatory step in the synthesis of acetylcholine. J Neurochem 26, 909-922 (1976)
28 Haubrich DR and Chippendale TJ: Minireview: Regulation of acetylcholine synthesis in nervous tissue. Life Sci 20, 14651478 (1977)

29 Carroll PT and Goldberg AM: Relative importance of choline transport to spontaneous and potassium depolarized release of acetylcholine. J Neurochem 25, 523-527 (1975)

30 Millington WR and Goldberg AM: Precursor dependence of acetylcholine release from rat cortex in vitro. Fed Proc 40, 268 (1981)

31 Blusztajn JK, Liscovitch M and Richardson UI: Synthesis of acetylcholine from choline derived from phosphatidylcholine in a human neuronal cell line. Proc Natl Acad Sci USA 84, 5474-5477 (1987)

32 Loullis CC, Dean RL, Lippa AS, Clody DE and Coupet J: Hippocampal muscarinic receptor loss following trimethyl tin administration. Pharmacol Biochem Behav 22, 147-151 (1985)

33 Kimmel EC, Fish RH and Casida JE: Bioorganotin chemistry. Metabolism of organotin compounds in microsomal monooxygenases systems and in mammals. J Agric Food Chem 25, 1-9 (1977) 